
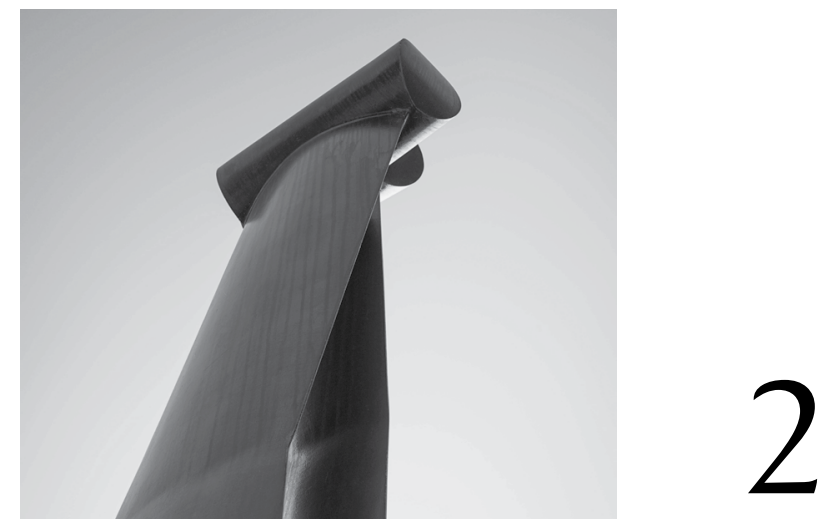

\title{
AN UNLIKELY TURNING POINT \\ Skin bleaching and the growth of colourism in South Africa
}

\author{
Nina G. Jablonski
}

We often consider turning points in history to be major singular events like assassinations, earthquakes, and military coups that have an immediate impact on public life or policy. Many significant turning points are not, in fact, singular events and - at the time they occur - are often not seen as momentous. Viewed in retrospect, though, they loom large because of their transformative power. The introduction of new products or the inauguration of popular trends can be turning points because they can affect how people go about their lives or think about themselves as conscious actors in society. Terence Turner's concept of "social skin" resonates here because skin itself acts as an interface for political, cultural, and social identity (Turner, 2012). In South Africa, the introduction of specific personal care products for the transformation of personal appearance, specifically the introduction of skin lighteners and hair straighteners, was an important, if unlikely, turning point. In the twentieth-century history of the country, these products made possible the alteration of perceived racial identity when "black" physical features were associated with inferiority and limited physical and social 
mobility. The continued use of these products after the apartheid era denotes their continued power to transform self-perception and to lessen the perceived burden of blackness.

Skin and hair are two of the most highly visible traits of the human body and the human social interface. These attributes are amongst the most important signifiers of age, ancestry, and attitude, and are some of the most important signals in the human nonverbal communication repertoire. People are assessed and judged by the appearance of their skin and hair (and clothing) and learn - in late childhood and adolescence - to navigate and manipulate social interactions by modifying the appearance of their skin, hair, and raiment. Modification of skin colour in the United States and South Africa is associated with multiple levels of social meaning because of its effects on race identity as well as on status within a race (colourism). In this chapter, I explore the specific effects of the development, commercialisation, and use of skin lighteners in apartheid era South Africa, and make the case that this innovation was a turning point in the history of race and racism in the country.

\section{Skin lightening in historical context}

Cultural preferences for light skin have arisen independently many times and have been reinforced when complementary "cultures of lightness" have come into contact with one another. The rise of agricultural and increasingly stratified economies throughout the Old World in the last 6000 years coincided with the division of populations into groups that spent most of their days working outdoors and those that spent the majority of their time indoors. The associations of darker, tanned skin with outdoor toil and hard physical labour and of light skin with relative leisure and affluence, led to light skin becoming a signal of higher social status in most agricultural societies worldwide (Jablonski, 2012). The public display of light skin was of great social importance in Eastern Asia and in Western Europe from the sixteenth through eighteenth centuries, but lightness took on new meanings and enhanced value as European colonies in the Americas prospered through the labour of imported dark-skinned slaves from Africa. Preferences for light or relatively light skin do not appear to have been widespread in Africa prior to widespread contact with Europeans, except in the Lower Nile of ancient Egypt, a hotspot of cultural and genetic intermingling. By Roman times, if not before, light skin was valued - especially in women - as a sign of privileged ancestry and lifestyle. Cleopatra (69-30 BC) took pains to keep her skin light, and her practice of bathing in asses' milk for the purpose of skin lightening is legendary but possibly apocryphal.

Having relatively light skin became synonymous with success and happiness, and people over the ages have sought to become lighter by various means (Jablonski, 2012). In parts of the world today, the sheer knowledge that a preference for 
lightness is associated with higher status elsewhere is sufficient to promote desires for skin lightening and sales of lightening products. Lighter appearing skin can be achieved by using whitening cosmetics, bleaching agents to decrease the production of melanin pigment in the skin, or a combination of both. Whitening cosmetics and skin bleaches have been used for nearly two thousand years, but only in the last century has the production of these materials become sophisticated, commercialised, and highly profitable.

Favoured formulas for skin lightening agents developed independently in Europe and East Asia. The popularity of white makeup and lightening preparations increased even though their toxic ingredients caused a myriad of health problems. Illness was not sufficient to discourage the use of white cosmetics and lighteners. However, for many, the drive to achieve social approval or advancement through lightness was worth the risk. What was remarkable about the history of skin whitening before the nineteenth century, was that it was the province of genetically light-skinned people. Those already light wanted to look lighter because whiteness signified freedom from outdoor toil as well as spiritual purity (Jablonski, 2012). Skin lighteners and lightening cosmetics took on different roles when they were adopted by people with dark skin, including dark-skinned South Africans living under Dutch and English colonial rule and the descendants of former slaves in the New World. Skin lightening agents have never been socially neutral; their use and effects have always been implicitly or explicitly political even if the people using them conceived only of their use in intensely personal terms. They were considered agents of increased social mobility and personal transformation to some, but instruments of subjugation to others.

In many parts of the world today, people with dark skin - regardless of their location or ethnicity - are considered inferior to those with light skin. Colourism is a type of skin colour bias that involves systematic discrimination against the relatively darkskinned within a particular group (Herring, Keith \& Horton, 2004; Hunter, 2007; Jones, 2000). Colourism has existed in many places for millennia because of the higher status accorded to people who could afford to spend their time indoors and lacked the darkened skin of those spending time outdoors. Colourism became more entrenched and institutionalised when people of visibly distinct skin colours lived in the same places and had offspring together. These conditions occurred widely in the Americas and the Caribbean during the centuries of the trans-Atlantic slave trade and during colonial and apartheid-era South Africa. Positive attitudes about lightened skin intensified in South Africa under the influence of people and ideas from the United States from the 1930s onward (Glenn, 2008; Thomas, 2012a), leading to a steady rise in colourism. As one could have predicted, the institution of the pass laws and apartheid ushered in a period of prodigious growth in the popularity of skin lightening preparations in the country. 
The commercial development of skin lighteners in the United States and South Africa

In social contexts of the United States and of other countries influenced by the colour consciousness of European colonialism, becoming lighter improved prospects for education and employment, social mobility, and marriage (Glenn, 2009; Hunter, 2005, 2007; Madrigal, 2006). In the United States, selective breeding towards whiteness was advanced as a long-term solution, but in the short term, many resorted to harsh chemicals to bleach their skin to more socially acceptable lightness (Jablonski, 2012). Development, production, and marketing of skin-bleaching products on a commercial scale began in the United States in the post-Reconstruction era, as segregationist "Jim Crow laws" restricted the opportunities and prospects of African Americans, especially in the South. By the mid-twentieth century, skin-bleaching products and practices began to have a significant sociological and economic impact on people and business in South Africa as well. With the installation and enforcement of apartheid in the 1950s and especially with the passage of the Coloured Labour Preference Act, which reserved certain jobs for people classified as "coloured", preference for people who could potentially pass as "coloured" became greater, and the popularity of skin-bleaching creams was not unexpected. Demand for skin lightening (and hair straightening) products seems to have been primed in earlier decades by the visits to South Africa by groups of missionary musical performers from the United States. Beginning at the turn of the twentieth century, these troupes (such as the Virginia Jubilee Singers) came to South Africa with a message of Christianised "racial uplift". With their talent and "smart and tidy" appearance including visibly straight hair and, in some cases, light skin, the performers became role models for South African modernity (Erlmann, 1991). Their performances in the major cities of South Africa in the 1890s were popular, and the fact that they were attended by influential South African political leaders like Paul Kruger (Erlmann, 1988) appeared to authorise their popularity with communities of South Africans of European ancestry. The net effect of their popularity for all South Africans was validation of their physical appearance and their Christian approach to entertainment.

\section{The rise of skin bleaching in South Africa}

The largest markets for skin lighteners have always developed in places where the social costs of darkness have been the greatest. Mercury-based skin bleaches were introduced into South Africa from the United States in the 1930s and became enormously popular, especially amongst people classified as "coloured" and "black". Skin lighteners were praised for "smoothening" the skin of the face, and for elevating the social status of both men and women. The company who 
manufactured skin bleaches in South Africa was the American-owned Apex Hair Inc., which was founded by Sara Washington in the 1930s to bring hair straightening products and skin bleaches to a mostly poor and working-class clientele. Apex emphasised use of products conducing to self-improvement and economic mobility (Thomas, 2009; Weinbaum, Thomas, Ramamurthy, Poiger, Dong \& Barlow, 2008). One of the ironies of the twentieth-century development of the skin-bleaching industry in South Africa was that it was connected strongly to African American entrepreneurship and the racialised role models that were common in the United States during the Jim Crow era.

During apartheid, black women in South Africa sometimes used skin bleaches to obtain jobs reserved for "coloured" women, but more often they parlayed a lighter appearance to enhance their prospects for engagement in social and employment settings that privileged light skin and a somewhat more European look. The unsightly skin blotches - sometimes denoting permanent damage to the skin that accompanied repeated use of skin lighteners were seen as positive evidence of being modern. Skin lighteners took away "the blackness". Darkly pigmented skin had become a disease in need of a cure.

It is impossible to know exactly how widely used skin bleaches were during the apartheid era, because many products were made by small companies and marketed locally. According to historian Lynn Thomas, however, skin lighteners had become so common in South African by the late 1960s that a 1969 survey showed that skin lightening creams were the fourth most commonly used household product after soap, tea, and tinned milk (Thomas, 2012b).

Thomas' studies of the history of use of skin bleaches in South Africa highlight the intersection of cosmetic technology, politics, and economics that lead to the increased popularity of lightening products during the apartheid years: "... the appeal and prevalence of these technologies of the self depended upon expansive political and economic structures that privileged light-coloured skin, made manufactured cosmetics widely available, and promoted their use through glossy magazines and local sales agents" (Thomas, 2009:203). The rise of some of South Africa's wealthiest and most influential industrialists, the Krok Brothers, was based on the coupling of modern production methods with clever packaging and ingenious advertising. The history of production and use of skin bleaches, and of opposition to the development and use of the products, demonstrates a dense interaction of racial hierarchies, capitalist commerce, and individual desires for betterment that parallel the American situation (Thomas, 2006, 2009, 2012b).

Opposition to skin bleaching in South Africa gained strength when anti-apartheid activists emphasised that lightening agents were loathsome products and should be avoided because they were harmful to health and to individual self-image. The 
"Black is Beautiful" campaigns of late twentieth-century South Africa probably had more long-term success in reducing the popularity of skin lighteners than those in the United States, because they combined social and medical information into comprehensive messages of personal empowerment and national pride (Thomas, 2012b). In 1990, South Africa became the first and only country in the world to prohibit advertisements for cosmetic products that made any claims to "bleaching", "lightening", or "whitening". Despite the combined action of social and medical activists, the market for skin lightening in South Africa has remained large, and cosmetics and skin-care companies have adapted their advertising vocabulary and ingredients in order to attract new users.

Skin lightening also receives boosts from the popularity of light-skinned celebrities whose images are widely circulated via social and conventional media and whose complexions are widely admired (Jablonski, 2011, 2012). Paradoxically, sales of skin lightening products increased in South Africa after 1994 because lighter skin and straighter hair were perceived as more modern and more professional (Jacobs, Levine, Abney \& Davids, 2016). It is far too simplistic to say that women (and the majority of consumers of skin lighteners are women) want to be white, but that retention of dark skin (and natural hair) reduces opportunities for professional training and advancement, and marriage prospects.

After mercury-based skin lighteners were banned in the United States in 1973, products containing hydroquinone or monobenzyle ether of hydroquinone became more popular there and in South Africa. However, mercurials were still considered the most efficacious, and illegal imports into South Africa of mercurial creams and soaps manufactured in Europe, Great Britain and Ireland persisted until the making of these products was finally discontinued in the early 2000s. Illegal products containing mercury and high percentages of hydroquinone can still be found in informal markets throughout South Africa, despite their illegality. When women can't afford to buy lighteners containing "safe" skin bleaches, they buy illegally imported hydroquinone-based products or resort to "under-the-counter", locally manufactured mercury-based compounds, often with disastrous effects (Davids, Van Wyk, Khumalo \& Jablonski, 2016).

South African and multinational companies have also been resourceful in extending their markets throughout sub-Saharan Africa. Selling hope has been easy when beauty, success, and happiness continue to be linked to lightness. Demand for skin lighteners is now high in African countries such as Nigeria, Ghana, Tanzania and Kenya with burgeoning economies and people eager to improve their status and prospects (Davids et al., 2016; Jablonski, 2012; Levine, Powell, Davids \& Jacobs, 2016; Street, Gaska, Lewis \& Wilson, 2015). Advertising has mostly targeted young women of marriageable age, but has been credited with helping to shift male preferences towards women with light-coloured skin. 
It is too simplistic to ascribe the use of skin lighteners to conformity under structural racism, because other motivations certainly enter into the complex personal decisions people are making about appearance (Jacobs et al., 2016). It is likely that people are making decisions based not only on perceived norms of physical attractiveness from the dominant world culture, but also on convenience, and because transformation of appearance relieves a level of psychological tension that they feel is generated in them when they interact with an unaltered appearance (Jablonski, 2011).

\section{Conclusion: The introduction of skin bleaches into South Africa was a genuine turning point}

The introduction of inexpensive products for transformation of physical appearance, especially of skin colour, towards more European-based norms in the mid-1950s was a significant turning point in South African history, because these products allowed people to personally negotiate and mitigate the psychological challenges of looking "too black". When a personal decision to use a product even a seemingly minor one affecting appearance - allows a person to feel more socially accepted and acceptable and affords them the possibility of enhanced personal financial gain through better employment or social associations, then the product and the decision-making process are elevated in historical importance. The promotion of skin lightening products in South Africa has been about selling the promise of a better appearance, leading to social elevation and happiness. For nearly a century, tens of thousands of South Africans have made personal decisions in front of their mirrors every day to lighten their skin, because they have felt that a lighter appearance would make them look better or would make their lives somehow easier. This is a dramatic, profound and tragic turn of events. 


\section{References}

Bonilla-Silva, E. \& Dietrich, D.R. 2009. The Latin Americanization of U.S. race relations: A new pigmentocracy. In: E.N. Glenn (ed.). Shades of Difference: Why Skin Color Matters. Stanford, CA: Stanford University Press.

Bonilla-Silva, E. \& Embrick, D.G. 2006. Black, honorary white, white: The future of race in the United States? In: D.L. Brunsma (ed.). Mixed Messages: Multiracial Identities in the "Color-Blind" Era. Boulder, CO: Lynne Rienner Publishing.

Broyard, B. 2007. One Drop. New York: Little, Brown and Company.

Davids, L.M.; Van Wyk, J.; Khumalo, N.P. \& Jablonski, N.G. 2016. The phenomenon of skin lightening: Is it right to be light? South African Journal of Science, 112(11/12). https://doi.org/10.17159/ sajs.2016/20160056

Erlmann, V. 1988. 'A feeling of prejudice'. Orpheus M. McAdoo and the Virginia Jubilee singers in South Africa 1890-1898. Journal of Southern African Studies, 14(3). https://doi. org/10.1080/03057078808708179

Erlmann, V. 1991. African Stars: Studies in Black South African Performance. Chicago, IL: University of Chicago Press.

Glenn, E.N. 2008. Yearning for lightness: Transnational circuits in the marketing and consumption of skin lighteners. Gender \& Society, 22(3). https://doi. org/10.1177/0891243208316089

Glenn, E.N. 2009. Consuming lightness: Segmented markets and global capital int he skin-whitening trade. In: E.N. Glenn (ed.). Shades of Difference: Why Skin Color Matters. Stanford, CA: Stanford University Press.

Golden, M. 2004. Don't Play in the Sun: One Woman's Journey Through the Color Complex. New York: Anchor Books.

Hall, R. 1995. The bleaching syndrome: African Americans' response to cultural domination vis-a-vis skin color. Journal of Black Studies, 26(2). https://doi. org/10.1177/002193479502600205

Herring, C.; Keith, V.M. \& Horton, H.D. (eds.). 2004. Skin/Deep: How Race and Complexion Matter in the "Color-Blind" Era. Urbana, IL: Institute for Research on Race and Public Policy and University of Illinois Press.

Hunter, M.L. 2002. "If you're light you're alright": Light skin color as social capital for women of color. Gender \& Society, 16(2). https://doi. org/10.1177/08912430222104895

Hunter, M.L. 2005. Race, Gender, and the Politics of Skin Tone. New York: Routledge.

Hunter, M.L. 2007. The persistent problem of colorism: Skin tone, status, and inequality. Sociology Compass, 1(1). https://doi. org/10.1111/j.1751-9020.2007.00006.x

Jablonski, N.G. 2011. Transforming "racial characteristics": Is it an appropriate role for aesthetic surgery? Aesthetic Surgery Journal, 31(3). https://doi. org/10.1177/1090820X11398113

Jablonski, N.G. 2012. Living Color: The Biological and Social Meaning of Skin Color. Berkeley, CA: University of California Press.

Jacobs, M.; Levine, S.; Abney, K. \& Davids, L. 2016. Fifty shades of African lightness: A bio-psychosocial review of the global phenomenon of skin lightening practices. Journal of Public Health in Africa, 7(2). https://doi.org/10.4081/jphia.2016.552

Jones, T. 2000. Shades of brown: The law of skin color. Duke Law Journal, 49. https:// doi.org/10.2307/1373052

Levine, S.; Powell, C.; Davids, L.M. \& Jacobs, M. 2016. Skin lightening/ bleaching. In: N.A. Naples, J.M. Ryan, R.C. Hoogland, M. Wickramasing \& W.C.A. Wong (eds.). The Wiley Blackwell Encyclopedia of Gender and Sexuality Studies. John Wiley \& Sons, Ltd. https:// doi.org/10.1002/9781118663219. wbegss 644 
Madrigal, L. 2006. The African slave trade and the Caribbean. Human Biology of AfroCaribbean Populations. Cambridge, MA: Cambridge University Press. https://doi. org/10.1017/CBO9780511542497

Norwood, K.J. \& Foreman, V.S. 2014. The ubiquitousness of colorism: Then and now. In: K.J. Norwood (ed.). Color Matters: Skin Tone Bias and the Myth of a Post-Racial America. New York: Routledge. https://doi. org/10.4324/9781315819334

Street, J.C.; Gaska, K.; Lewis, K.M. \& Wilson, M.L. 2015. Skin bleaching: A neglected form of injury and threat to global skin. African Safety Promotion, 12(1). https://hdl.handle.net/10520/EJC159577

Thomas, L.M. 2006. The modern girl and racial respectability in 1930s South Africa. The Journal of African History, 47(3). https://doi.org/10.1017/ S0021853706002131

Thomas, L.M. 2009. Skin lighteners in South Africa: Transnational entanglements and technologies of the self. In: E.N. Glenn (ed.). Shades of Difference: Why Skin Color Matters. Stanford, CA: Stanford University Press.
Thomas, L.M. 2012a. Imported Cosmetics and Colonial Crucibles: Pre-histories to the Twentieth-century Use of Commercial Skin Lighteners. Paper presented at the Wiser Seminar Series. University of the Witwatersrand, 23 July.

Thomas, L.M. 2012b. Skin lighteners, black consumers and Jewish entrepreneurs in South Africa. History Workshop Journal, 73(1). https://doi.org/10.1093/hwj/ dbr017

Turner, T.S. 2012. The social skin. HAU: Journal of Ethnographic Theory, 2(2). https://doi.org/10.14318/hau2.2.026

Weinbaum, A.E.; Thomas, L.M.;

Ramamurthy, P.; Poiger, U.G.; Dong, M.Y. $\&$ Barlow, T.E. 2008. The modern girl around the world: Cosmetics advertising and the politics of race and style. In: A.E. Weinbaum, L.M. Thomas, P. Ramamurthy, U.G. Poiger, M.Y. Dong \& T.E. Barlow (eds.). The Modern Girl Around the World: Consumption, Modernity, and Globalization. Durham, NC: Duke University Press. https://doi. org/10.1215/9780822389194 


\section{JPPR@SS VOLUMES IN THE SERIES}
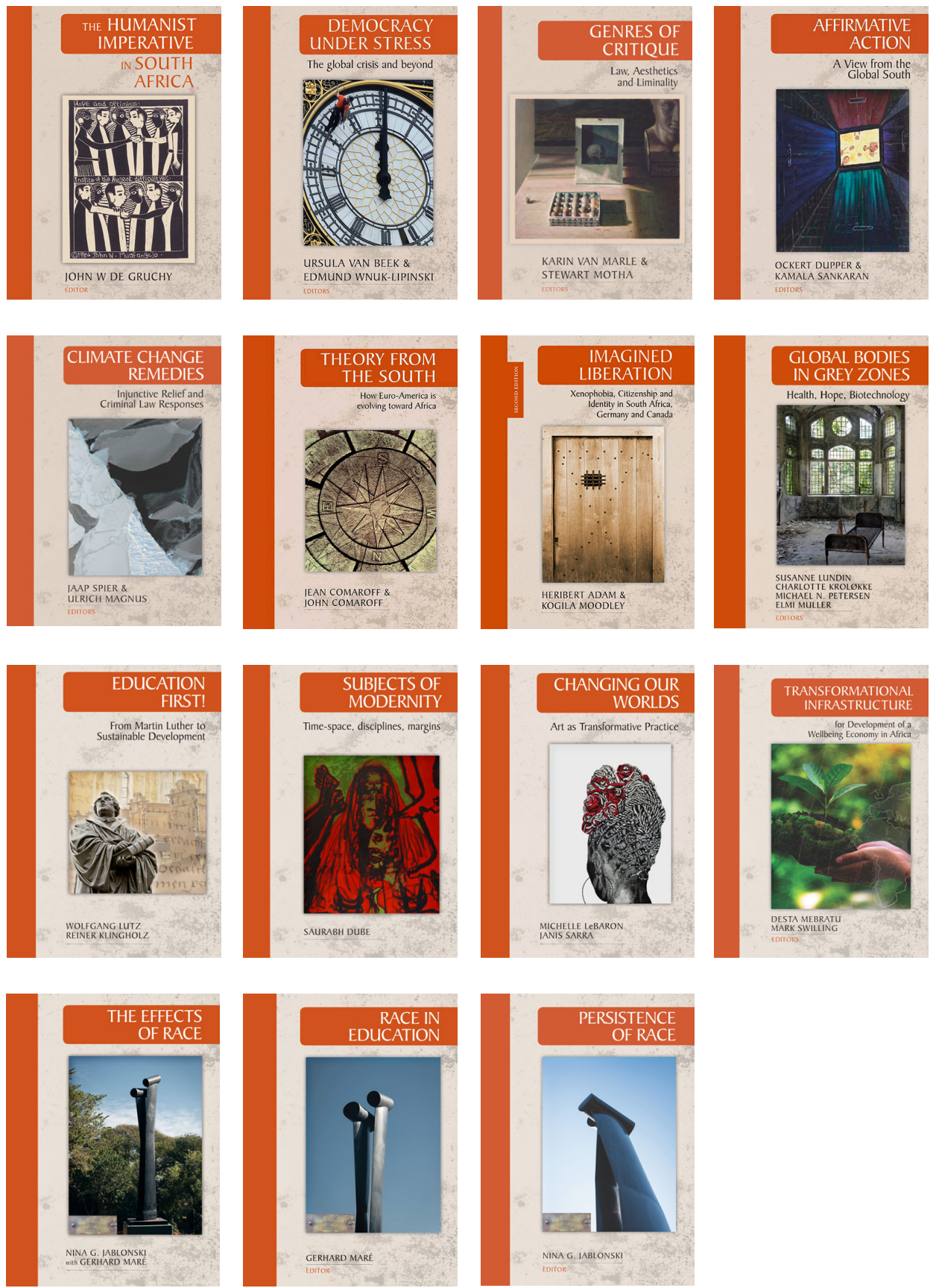